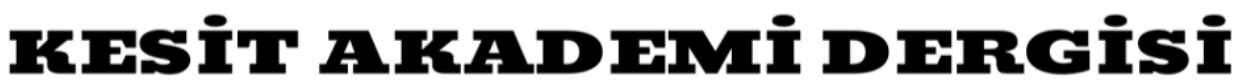 \\ ISSN= 2149-9225 \\ The Journal of Kesit Academy
}

\section{Yazınsal Metinde Sözcelerin “Etkisöz" Bağlamında İncelenmesi}

Analysis of Utterance in The Literary Text in The Context of "Perlocution"

\author{
Selim YILMAZ* \\ Nezihe KARA**
}

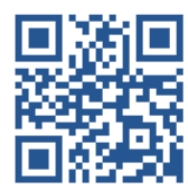

Makale Türü/ Article Information/ Информация о Статье:

Araştırma Makalesi/ Research Article/ Научная Статья

\section{Atıf / Citation / Цитата}

Yılmaz, S. ve Kara, N. (2021). Yazınsal metinde sözcelerin "etkisöz" bağlamında incelenmesi. Kesit Akademi Dergisi, 7 (29), 241-259.

Yılmaz, S. \& Kara, N. (2021). Analysis of utterance in the literary text in the context of "perlocution". The Journal of Kesit Academy, 7 (29), 241-259.

\author{
dol $10.29228 /$ kesit.52627 \\ Geliş/ Submitted/ Отправлено: \\ 14.09.2021 \\ Kabul/ Accepted/ Принимать: \\ Yayın/ Published/ Опубликованный: \\ 25.12.2021
}

Bu makale İntihal.net tarafından taranmıştır. This article was checked by Intihal.net. Эта статья была проверена Интихал.нет Bu makale Creative Commons lisansı altındadır. This article is under the Creative Commons license. Это произведение доступно по дицензии Creative Commons.

*Prof. Dr., Marmara Üniversitesi, selimy26@gmail.com

**Öğr. Gör., Sivas Cumhuriyet Üniverstesi, karanezihe@yahoo.fr 


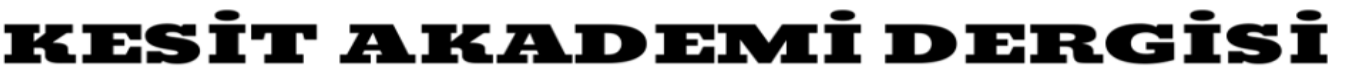 ISSN= 2140-9225 The Journal of Kesit Academy
}

\author{
Yazınsal Metinde Sözcelerin “Etkisöz" Bağlamında İncelenmesi' 2 \\ Analysis of Utterance in The Literary Text in The Context of "Perlocution"
}

\section{Prof. Dr. Selim YILMAZ}

Öğr. Gör. Nezihe KARA

Öz: Yıllarca “Edebiyat ve Dilbilim” alanları gerek yazınsal alanda gerekse de bilimsel anlamda birbirini karşılıklı olarak beslemiş ve destek olmuşlardır. Bu açıdan bakıldığında, Edebiyatı Dilbilimden, Dilbilimi de Edebiyattan ayırmak, ayrı ya da bağımsız görmek ve değerlendirmek mümkün değildir. Bu nedenle, sosyal bilimlerde çokdisiplinli bir bakış açısının dikkate alındığı ve bilhassa disiplinlerarasılık yaklaşımının sergilendiği çalışmalar tüm dünyada son yıllarda ivme kazanarak kayda değer hale gelmiştir. $\mathrm{Bu}$ bağlamsal çerçevede çalışmamızın kısaca tanıtımını yapmak gerekirse, bu makalede 19. yüzyıl Fransız Edebiyatında Doğalcılık (Natüralizm) Akımının öncüsü Emile Zola'nın Claude'un İtirafları (Fr. La Confession de Claude) adlı romanından yola çıkarak eserden seçilen bazı sözceler Söylem Dilbilimi yaklaşımıyla "Etkisöz" (Fr. Perlocution) bağlamında incelenecektir. Metnin derin okumasını yaptıktan sonra romanda geçen etkisözler taranarak dilbilimsel yaklaşım doğrultusunda sınıflandırılacak ve yorumlanmaya çalışılacaktır. İncele-menin püf noktası, etkisöz barındıran sözcelerin ne tür dilsel gösterge barındırdığı sorusunu/sorunsalını mümkün olduğunca ay-

1 “COPE-Dergi Editörleri İçin Davranış Kuralları ve En İyi Uygulama İlkeleri” beyanları: Bu çalışma için herhangi bir çıkar çatışması bildirilmemiştir. Bu çalışma için etik kurul onayı gerekmemektedir. Bu çalışma Marmara Üniversitesi BAP Birimi tarafından SOS-B-071015-0490 kodlu proje kapsamında desteklenmektedir. Çalışmaya sunduğu değerli katkılardan dolayı Ayşe Sezer Hanım'a teşekkürü bir borç biliriz. Katkı Oranı Beyanı: \%80-\%20. Sorumlu Yazar: Selim YILMAZ

Statements of "COPE-Code of Conduct and Best Practices Guidelines for Journal Editors": No conflicts of interest were reported for this article. Ethics committee approval is not required for this article. This work is supported by Marmara University BAP Unit under the project code SOS-B-071015-0490. Author Contributions: \%80-\%20. Corresponding Author: Selim YILMAZ

${ }^{2}$ Çalışmada Batı Dilbilimi kuramından yararlanıldığından (Fransız Söylem Dilbiliminde Sözceleme Kuramı), bazı özel dilbilimsel terimlerin daha iyi anlaşılabilmesi amacıyla orijinal Fransızca ya da İngilizce karşılıkları parantez içinde verilecektir. Türk dilbiliminde "sözceleme" nin yanı sıra "Sözcelem" terimi de kullanılmaktadır. 
dınlatabilmektir. Çalışmanın temel amacı, bir edebiyat metninde "etkisöz" kavramina belirli bir anlam, sinıflandırma ve boyut kazandırmak ve bu konuda alana bir katkı sağlayabilmektir. Çalışmada, Genel Dilbilimin kurucusu Ferdinand De Saussure'den başlamak üzere, çağdaş batı dilbilimi kapsamında Fransız Dilbiliminde önemli bir yere sahip olan "Sözceleme" (Fr. Énonciation) kuramı ve "Söylem Çözümlemesi" (Fr. Analyse du discours) yönteminden yararlanılacaktır. Bu kapsamda araştırmanın özü, bir edebî romanda dilsel kullanım olarak etkisözlerin göstergeler vasıtasıyla içerdikleri anlamları çok yönlü ya da çok boyutlu pragmatik bir yaklaşımla açıklamaktır.

Anahtar Kelimeler: Söylem dilbilimi, sözceleme, Emile Zola, etkisöz, gösterge.

Abstract: For years, the fields of "Literature and Linguistics" have mutually fed and supported each other both in the literary and scientific sense. From this point of view, it is not possible to separate Literature from Linguistics and Linguistics from Literature, to see and evaluate them separately or independently. For this reason, studies in which a multidisciplinary perspective is taken into account in social sciences and especially the interdisciplinarity approach is exhibited have gained momentum all over the world in recent years and have become noteworthy. To briefly introduce our work in this contextual framework, in this article based on Pioneer of the Naturalism (Fr. Naturalisme) Movement in 19th Century French Literature Emile Zola's novel Claude's Confessions (Fr. La Confession de Claude) some of the utterances selected from the work will be analyzed in the context of "Perlocution" (Fr. Perlocution) with the Discourse Linguistics approach. After a deep reading of the text, the perlocutions in the novel will be scanned, classified and interpreted in terms of linguistic approach. The key point of the analysis is to illuminate as much as possible the question / problematic of what kind of linguistic signs do perloctions contained in the expressive utterances. The main purpose of the study is to give a certain meaning, classification and dimension to the concept of "Perlocution" in a literary text and to make a contribution to the field in this regard. Starting from Ferdinand De Saussure, the founder of General Linguistics, the theory of "Enunciation" (Fr. Énonciation) with "Analysis of Discourse" (Fr. Analyse du discours), the method which has an important place in French Linguistics within the scope of contemporary western linguistics, method will be used. In this context, the essence of the research is to explain the meanings of perlocutions (perlocutive utterances) through signs as linguistic use in a liter- 
ary novel with a multi-faceted or multi-dimensional pragmatic approach.

Keywords: Discourse linguistics, enunciation, Emile Zola, perlocution, sign.

\section{Giriş}

Dilin ne olduğu ya da dilin işlevleri konusu yüzyıllardır tartışılagelen bir konu olmuştur. Dil konusuna farklı açılardan bakılmış ve dilin yapısını çözümlemek, onu anlamak için farklı metotlar geliştirilmiştir. Bu metotlardan dilbilimsel ve göstergebilimsel yaklaşımlar, yazılı ve sözlü dile tabir yerindeyse daha bilimsel ve derinlemesine yaklaşmayı amaçlar. Tümce, dilbilgisi kurallarına uygunluk gösterip sözdizimine uygun dilsel yapılar üretirken, sözce ise bunlarla birlikte bağlamsal anlam ve sözcelemsel değger (Fr. valeur énonciative) ${ }^{3}$ itibariyle daha derin bir yapıyı içine alır. Sözceleme kuramı çerçevesinde, "sözce"de konuşan özne (Fr. sujet parlant) olgusu esas alındığ1 için tümceye kıyasla daha kısa olabildiği gibi, bünyesinde çeşitli öznel yargı ve duyguları da barındırabilir. ${ }^{4}$

Aynı zamanda sözceyi zaman ve uzamdan yani bağlamından ayrı tutmak mümkün değildir. Buna söylem dilbiliminde "sözceleme durumu ve anı" (Fr. situation et moment de l'énonciation) deniyor. Sözce ulamları arasında en dikkat çekenlerden birisi de "etkisöz"dür (Fr. perlocution). Genel olarak bir dil kullanıcısının ya da konuşucunun dil yoluyla karşı tarafa verdiği etkiyi anlatan bu kavramın tasvir ettiği sözce yap1sı, kiplikler, adıllar, söz sanatları gibi çeşitli dilsel olgu ve oluşumların yerinde ve doğru kullanımları sonucu ileti gönderimi ya da aktarımı bakımından amaçlarına ulaşırlar. Buradan hareketle, Emile Zola'nın Claude'un İtirafları adlı eserinden yola çıkarak eserden seçilen bazı sözceler söylem dilbilimi yaklaşımıyla "Etkisöz" bağlamında sınıflandırılarak analitik ve pragmatik bir bakış açısıyla yorumlanmaya çalışılacaktır. Fakat, çalışmanın analitik kısmına geçmeden önce araştırmanın kuramsal altyapısını oluşturması bakımından başlangıçta Saussure Dilbilimini kısaca hatırlatmakta yarar görüyoruz.

\section{Saussure Dilbilimi}

Dünyada dilbilimsel çalışmaların temelini atan ve bu alandaki fikirlerin gelişi-

\footnotetext{
${ }^{3}$ Çalışmada Batı Dilbilimi kuramından yararlanıldığından (Fransız Söylem Dilbiliminde Sözceleme Kuramı), bazı özel dilbilimsel terimlerin daha iyi anlaşılabilmesi amacıyla orijinal Fransızca ya da İngilizce karşılıkları parantez içinde verilecektir. Türk dilbiliminde "sözceleme"nin yanı sıra "Sözcelem" terimi de kullanılmaktadir.

${ }^{4}$ Sosyal Bilimlerde "Dilbilim ve Edebiyatın" çokdisiplinli ve disiplinlerarası çerçevede birbirini destekleyen temel alanlar olduğu düşünüldüğünde, yükseköğretim kurumlarımızın Edebiyat Bölümlerinde mutlak surette çeşitli dilbilim derslerinin konulmasında yarar vardır. Birçok üniversitemizin Batı ya da Türk Edebiyatı Bölümlerinde Dilbilim derslerinin hiç olmadığını üzülerek görmekteyiz. Eğitimdeki bu önemli eksikliğin giderilerek bahse konu bu yanlıştan bir an evvel dönülmesinde yarar vardır. Bunun ileride bilimsel araştırmalara da olumlu yansımalarının olacağı aşikârdır. Zira dilini bilmeyen ya da diline hâkim olmayan bir dil kullanıcısı kuşkusuz edebiyatını da kültürünü de bilemez, anlayamaz. Gerçek anlamda özümseyerek, içselleştirerek anlaması ve kavraması mümkün değildir. Dolayısıyla, özellikle yükseköğretim seviyesinde bu manada edebiyatı dilbilimle desteklemenin kaçınılmaz olduğu ortadadır. Yetkili kişi ve mercilerin bu durumu artık en kısa zamanda dikkate almalarını umuyoruz.
} 
mine zemin hazırlayan kişi, İsviçre asıllı ünlü frankofon dilbilimci Ferdinand de Saussu$r e^{\prime}$ dür. Bu yönüyle, dünyada Dilbilimin kurucusu olarak bilinir. Vardar'in (1998: 12) ifadelerine göre Saussure daha çok Yapısalcılık (Fr. structuralisme) ve Göstergebilim (Fr. sémiotique) alanlarında tanınmış olmakla birlikte, tabiri yerindeyse 20. Yüzyılda dilbilimin babası olarak da anılır. Saussure'ün yapısalcılığının temel ilkeleri, çift kavram ilişkileri yani dikotomiler (Fr. dichotomie) ${ }^{5}$ üzerine kuruludur. Bunun altında, dünyadaki her şeyin çift yaratıldığı ve bir kavramın doğru anlatılabilmesi için karşıt anlamına da ihtiyaç olduğu fikri yatar. Saussure yapısalcılığının temel ilkeleri dikotomik çift kavramlar ilişkisi bünyesinde, dil - dil yetisi, dil - söz, bireysel - toplumsal, eşzaman - artzaman, gösteren- gösterilen, dizisel - dizinsel ayrımı gibi çeşitli eksen konularını barındırır. Her dil yapısal olarak kendi içerisinde belli kurallara ait özellikler barındırırken, o dilin ait olduğu toplumun zihinsel ve kültürel anlayışları da dile etki edecek ve doğal olarak da dil bu bağlamda şekillenecektir. Bu eksende, dilsel olguları anlatmanın en etkili yolu yukarıda zikredilen dikotomilerdir ki bunu bir şemayla şu şekilde gösterebiliriz:

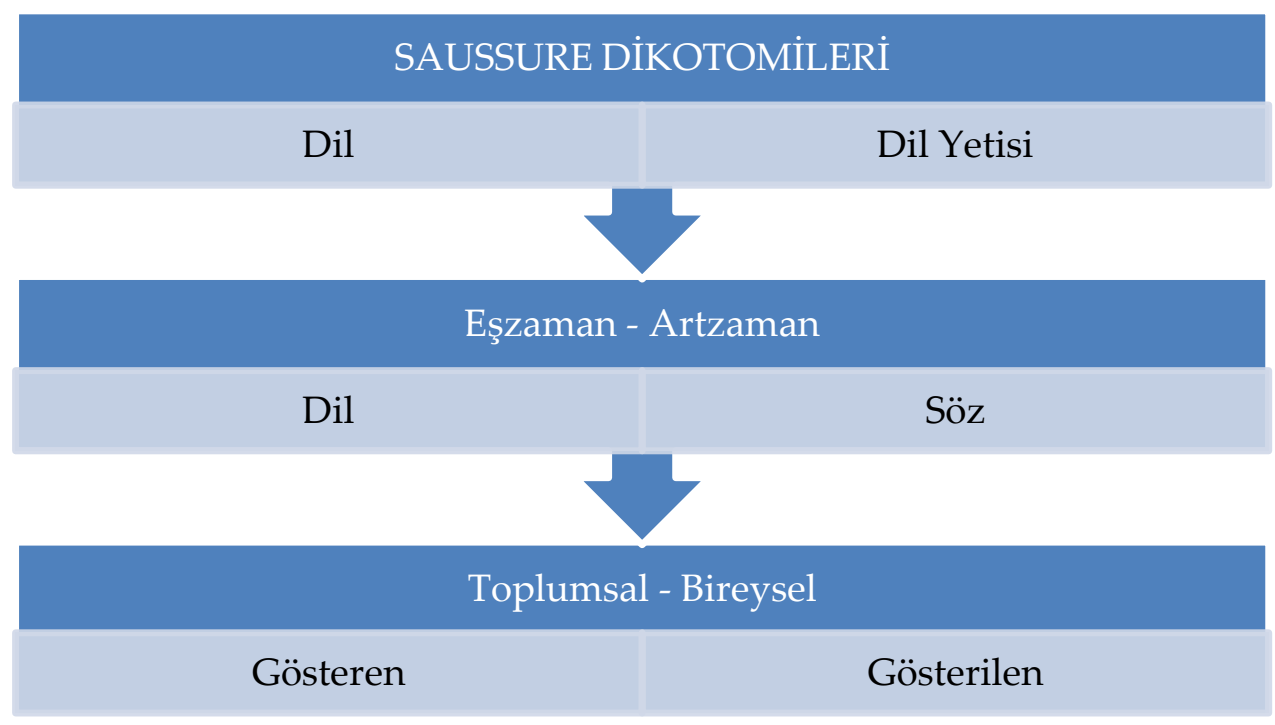

Şekil 1: Saussure ve dikotomik çift kavramlar

19. yüzyılda insanı daha doğrusu birey üzerinden toplumu anlama çalışmaları kültürel ve psikolojik anlamda başlamış, sonrasında dil ve kültür ilişkisi bağlamında farklı bakış açıları geliştirilmiştir. Dil ve kültür kavramları farklı konular gibi görülse de "Dil mi kültürü yoksa kültür mü dili oluşturur?" sorusu tartışılagelen bir konu olmuştur. Konumuzun dilbilimsel konular ${ }^{6}$ içerisinde yer alması itibariyle "sözce ve etkisöz" konularından bahsetmeden önce, dilbilimin görevlerinden bahsetmemizde fayda olacağını düşünüyoruz. Dil genel ya da en temel göreviyle, karşı tarafa kendini anlatabilme amacını güder. Bilinen ilk işlevi olan bu durum, dilin ne olduğu ya da ne işe yaradığı konusuna kapsamlı cevap verememekle birlikte dilin altında yatan derin anlamı

${ }^{5}$ Tek kelimelik tam karşılığı olmayan bunun gibi kimi dilbilimsel kavramlar Türkçede, daha doğrusu Türk Dilbiliminde ödünçleme yoluyla olduğu gibi kullanılmaktadır.

${ }^{6} \mathrm{Bu}$ araştırma tam olarak uygulamalı söylem dilbilim ve sözceleme dilbilimi alanına girmektedir. Diğer yandan bir yazarın sadece bir romanı ele alındığından dolayı bir durum çalışması olarak görülmelidir. 
ve dilin bilimselliğini de ortaya çıkarmakta yeterli olamayabilir.

Büyük ölçüde Saussure ile başlayan dilbilimsel çalışmalar, Moskova Üniversitesi akademisyeni Trubetzkoy, yapısalcı dilbilimci Bloomfield, Edimbilim (İng. pragmatics) ve Anlambilim (İng. semantics) ayrımını yapan Austin ile devam etmiş ve çağdaş yapısalcılarından Chomsky ile günümüzde dilin derin yapısıly ilgili çeşitli konular üzerinde çok yönlü araştırmalar sürmektedir. Dilbilim genel itibariyle, dilin betimlemesini yaparken sözdizimsel ve sesbilgisel konular (Fr./Ing. phonème, phonem; syntaxe, syntax) ile birlikte biçim (Fr./İng. forme, structure) ve anlamı (İng. meaning, sense) ilişkilendirmek suretiyle dikkate alır. Zira bunlar dilin derin yapısında birbirine oldukça bağlı dikotomilerdir.

Bunun sonucunda, adından da anlaşılacağı gibi dilbilim, dili daha mantıksal ve bilimsel bir çerçevede incelemeye başlamış ve karşımıza bu bağlamda iki faklı görüş çıkmıştır: Amerikan Yapısal Dilbilim Okulu ve Üretici Dönüşümsel Dilbilgisi Okulu. $\mathrm{Bu}$ oluşumları ve temsilcilerinin anlayışlarını kısaca özetlemek gerekirse, Amerikan Yapısalcılığının başlıca temsilcisi olan Bloomfield, insanın davranışları gibi dilyetisinin (Fr. langage, İng. language $)^{7}$ de bütünüyle dış koşullarla açıklanabileceğini savunmuştur. Bloomfield'e göre dilbilimci somut metnin gereci olan bütünce (Fr./İng. corpus), yani bir dili çözümlemek amacıyla derlenmiş sözlü ya da yazılı örnekler bütünü üzerinde çalışılmalıdır. Üretici Dönüşümsel Dilbilgisi Okulunun en önemli temsilcisi Chomsky'dir. Chomsky'ye göre, her dilin sahip olduğu kurallar bütünü vardır ve bu kurallar dilbilgisini oluşturur. Fakat insanlar, günlük hayatlarında bu kuralları bilmeden yaşar ve konuşurlar. Bu durum bize, her konuşucunun kendi anadili konusunda sezgisel bilgilere sahip olduğunu gösterir. Bu bilgi, iletişim için gerekli olan "örtük dilbilgisi"dir (derin yapı / İng. deep structure). Fakat asıl mesele dili betimlemek, çözümlemek ve biçime sokmaktır. Bu da "belirtik dilbilgisi" (yüzeysel yapı / İng. surface structure) kapsamindadir.

Dilin toplumsal, sözün (Fr. parole/ İng. speech) ise bireysel bir nitelikte olması, dilsel edim (performans) açısından kişisel üretim biçimi olan söylem ve sözcenin yapısal yani sözdizimsel oluşumunu ortaya koyar. Bu sebepledir ki sözcede, dil kullanıcı olarak konuşan özne (Fr. sujet parlant) olgusu hâkimdir. Austin, iletişim esnasında söz edimi üretirken, üç ayrı edim gerçekleştirdiğimizi belirtmektedir (Onursal-Ayırır, 2016: 148). Bunlar düzsöz, edimsöz ve etkisöz edimleridir. Belli sayıda kurallar çerçevesinde sayısız sözce üretilebilir, bu üretme gücüne "düzsöz" denmektedir. Sözcenin içerdiği bilgi türüne göre konuşanın bir niyeti gerçekleştirmesine "edimsöz" (söz verme, uyarma, bilgi verme, eleştirme vb.), sözcenin alıcı üzerinde yarattığı etkiye ise "etkisöz" denmektedir (Gürata, 2018: 282). Aşağıdaki şekilde gösterilen bu 3 farklı söz ediminden biz daha ziyade "etkisöz" üzerinde yoğunlaşacağı.

\footnotetext{
${ }^{7}$ Fransız Dilbiliminde "Dil - Dilyetisi" dikotomisi “Langue - Langage" (Bkz. Saussure) şeklinde iki ayrı terimle karşılanırken, İngiliz Dilbiliminde ise iki kavramdan oluşan bu dikotomi "Language - Language" şeklinde aynı terimle karşılık bulmaktaysa da bunların farklı dilsel olgulara işaret ettiği bilinen bir gerçektir. Dolayısıyla, iki terimin konu edildiği yerde mesela "Language (a) - Language (b)" yahut da "Language (1) - Language (2)" şeklinde kodlanmak suretiyle ayırt edilmesinde yarar vardır.
} 


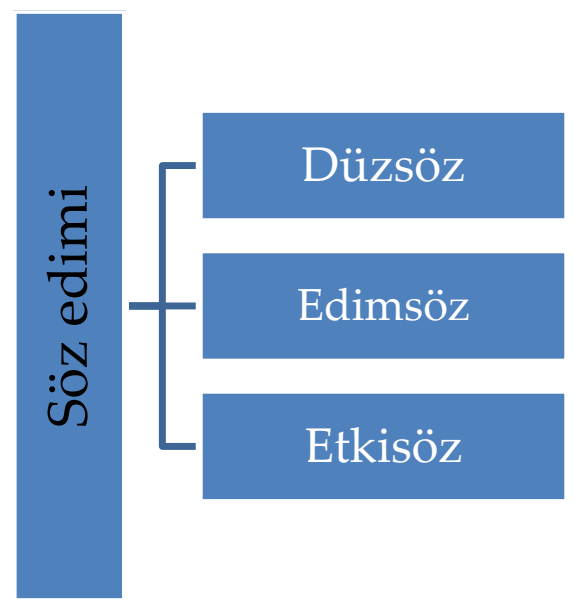

Şekil 2: Söz ediminin 3 farklı sınıfı

\section{Etkisöz Nedir?}

Konumuz gereği, romandaki sözceler etkisöz bağlamında inceleneceğinden, konunun detaylı anlatımı ve dildeki işlevlerinden bahsetmemizde yarar olacağını düşünüyoruz. Etkisöz genel itibariyle Vardar'ın Dilbilim Terimleri Sözlü̈̆̈̈̈nde şu şekilde açıklanır: Konuşucunun dinleyici üzerinde dolaylı biçimde bir etki yapmasını sağlayan bildiri. Örneğin bir seçim söylevinde etkisöz coşkuya, belli bir sava inanmaya yol açabilir (2007: 97). Etkisöz, dilde öznellik ya da evrensellik açısından iki boyutlu dikotomi incelendiğinde, söyleyen - dinleyen / konuşan - muhatap (bireysel, karşıllklı konuşma) ile gönderici - alıcı (daha genel ve toplumsal) ${ }^{8}$ şeklinde iki farklı etkileşim boyutu olarak kendini gösterir.

Etkisözün en önemli görevi, bilhassa alıcıda, duyusal, düşünsel ve/veya beden dili olarak fiziksel bir harekete sebep olmasıdır. Adından da anlaşılacağı üzere, karşı tarafa etki eden özne olarak bir gönderici, nesne olarak da bir ileti olması gerekir. Diğer alanlarda da kendini gösteren bu üçlü boyut, dilde, gönderici-ileti-alıcı şeklinde kendini gösterecek ve üçlü bir etkileşim düzleminden söz etmemizi sağlayacaktır. Misal bir devlet adamının söylemi ve hitap şekli, -mesajı ve üslûbu- etkisöz bağlamında değerlendirilirken, hitap ettiği kesimin toplum olması ve etkilemeye yönelik olması, etkisöz döngüsüne somut bir söylem örneği olarak gösterilebilir.

Öznellik boyutunda ise, ünlü bir düşünür yahut yazarın özlü sözleri, hayatta herhangi bir sosyal soruna ya da kültürel bir olguya dair kısa ve net söylemleri de toplulukları etkilemesi bakımından etkisöz kapsamında düşünülebilir. Bu gibi odaklayıcı söylemler yıllarca toplumlarda iz bırakmış, insanların hafızalarında yer edinmiştir. Buna en güzel örnek olarak Fransız Edebiyatından sayısız yazar ismi vermek mümkündür; zira Victor Hugo, Honoré de Balzac, Emile Zola, Gustave Flaubert gibi isimler sadece edebiyatçı yazar değil, aynı zamanda klasikleşmiş, unutulmazlar arasında yerini alan öncü düşünürler, felsefe adamlarıdır.

\footnotetext{
${ }^{8}$ Fransız Dilbiliminde bu kavramların karşılığ “locteur - interlocuteur" (söyleyen - dinleyen / konuşan - muhatap) ve "émetteur - récepteur" ya da "destinateur - destinataire"dir (gönderici - alıc1).
} 
Yine etkisöz konusuna örnek olarak vereceğimiz dikotomilerden gönderici - alıcl, belirtik anlam - örtük anlam, yan anlam - düz anlam gibi olguları, kısaca örneklendirmek ve açıklamak gerekirse, net ve keskin bir söyleyişin kişi ya da toplumlar üzerindeki etkisi (emir ve ünlem tümceleri gibi) ya da mecaz gibi söz sanatı kullanımı, bağlam çerçevesinde sözlerin etkisini arttırır, pekiştirir ve karşı tarafta belirli bir etki uyandırır. Diğer taraftan, Emile Zola toplumlarda iz bırakmış klasik yazarlardan olduğundan günümüzde de etkisini sürdürmektedir. Bu bağlamda etkisöz konusu üzerine bir çalışmaya rastlanılmaması sebebiyle, Zola'nın bu romanından hareketle aşağıda sunulacak tablolarda yer alan örneklerden yararlanılacak, etkisöz kapsamına giren seçili sözceler dilsel değerlerine göre sınıflandırılarak açılanmaya ve yorumlanmaya çalışılacaktır.

Edebiyatta etkisöz bağlamında, Emile Zola'nın doğalcılık akımına (Fr. naturalisme) mensup bir yazar olması, dil kullanımı ister istemez etkilemiştir. Zola diline yansıyan doğal unsurlar aşağıda incelenecek sözcelerde somut olarak görülecektir. Söyleminde olabildiğince sansürden uzak, doğallığ 1 ve şeffaflığ1 tercih etmesi, karş1lıklı konuşmalar şeklinde cereyan eden sözlü dil kullanımının yoğunluğunu da beraberinde getirmektedir. Karşılıklı konuşmaların sıklıkla kullanılması, öznel değeri olan kısa ve etkili sözceler başta olmak üzere, biçemsel açıdan yerine göre çeşitli söz sanatlarının da yerine göre birer etkisöz olarak metinde yer almasını gerektirmiştir. Bu durumu aşağ1daki şekilde göstermeye çalışalım:

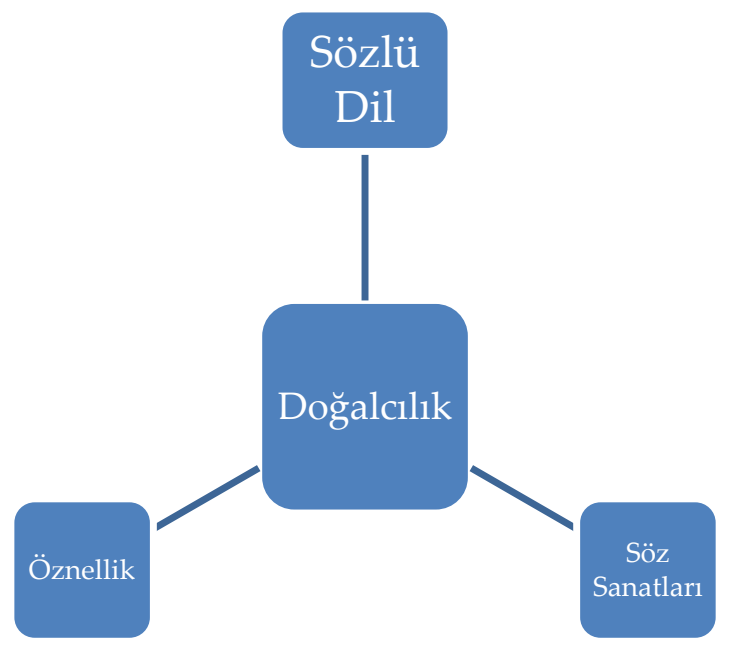

Şekil 3: Doğalcılığın özellikli bileşenleri

\section{3. Öznellik İçeren Etkisözler}

Etkisözü arayabileceğimiz en uygun kaynaklardan biri öznel yargılar içeren ifadelerdir. Ünlü yazar yahut düşünürlerin kaleme aldığı deneme, roman vb. türler, toplulukları etkileyen söz ve sözceler açısından zengin bir kaynak olarak görülür. Bu sebeple, etkisöz bağlamında değerlendireceğimiz olgulardan biri de öznelliktir. Aşağıdaki tabloda öznellik içeren etkisözlü sözceler ve barındırdıkları çeşitli dilsel göstergeleri incelediğimizde, öznellik göstergelerinin daha çok yüklem yapısında göründüğ̈ü göz- 
lemlenebilir; buradaki biçimbirimsel gösterge 1.tekil şahıs ekidir. Bunun yanı sıra, "ben, benim" gibi kişi adılı ve biçimbirim olarak iyelik ekleri şeklinde de karşımıza çıkmaktadır.

Tablo 1: Öznellik İçeren Etkisözlü Sözceler

\section{ÖZNELLIKK İÇEREN ETKISÖZLER}

\section{\begin{tabular}{l} 
ETKİSÖZLÜ SÖZCELER \\
\hline 1. Dinliyorum, ancak üzüntü duyabiliyorum. (s.14)
\end{tabular}}

2. Yoksa yaşından önce adam olmak isteyen bir çocuk muyum? (s.16)

3. Tanrının hoşgörüsünü insanların zenginliğine tercih ederim. (s.17)

4. Ve suskunluk: bu sessizlikte kalbimin hıçkırıklarını duyuyorum. (s.14)

5. Ne istiyorsunuz kardeşlerim, ilk adımım hüzünlü oldu: ilerlemeye cesaret edemiyorum. Ac1ma son verip, tüm gözyaşlarımı dökeceğim ve gülmeye yeniden başlayacă̆ım. Yarın daha neşeyle çalışacağım. (s.33)

\section{DİLSEL GÖSTERGELER}

Gösterge 1= Dinliyor-u-m (1. tekil şahıs eki). Öznellik göstergesidir.

Gösterge 2= Duyabiliyor-u-m (1. tekil şahıs eki). Öznellik göstergesidir.

Gösterge 3= (Ben) Dinliyorum... duyabiliyorum (Gizli özne olgusu vardır). Öznellik göstergesidir.

Gösterge 1= Çocuk mu-y-u-m? (1. tekil şahıs eki). Öznellik göstergesidir.

Gösterge 2= Gizli özne olan "Ben" zamiri bulunur. Öznellik göstergesidir.

Gösterge 1= Tercih eder-i-m (1. tekil şahıs eki). Öznellik göstergesidir.

Gösterge 2= Gizli özne olan "Ben" zamiri bulunur. Öznellik göstergesidir.

Gösterge 1= Duyuyor-u-m (1. tekil şahıs eki). Öznellik göstergesidir.

Gösterge 2= (Ben) duyuyorum (Gizli özne olgusu vardır). Öznellik göstergesidir.

Gösterge 1= (Benim) adım-1-m (1. tekil şahıs iyelik eki). Öznellik göstergesidir. Gösterge 2= (Ben) edemiyor-u-m (1. tekil şahıs eki). Öznellik göstergesidir.

Gösterge 3= (kendi/benim) gösyaşlar-1m (1. tekil iyelik eki). Öznellik göstergesidir.

Gösterge 4= (Ben) dökecek-i-m (1. tekil şahıs eki). Öznellik göstergesidir.

Gösterge $5=($ Ben) çalışacak-1-m (1. tekil şahıs eki). Öznellik göstergesidir. 
6. Ben, dostlarım, hüzünle yaşarım: Benim için kış mevsimi baharsız geçer. Nemli merdivenlerin üstündeki çatı katım geniş ve dağınıktır... (s.13)

7. (...) üzerimde iç karartıcı ve donuk bir sıkıntının ağırlığını hissediyorum. (s.13)

8. Dünyayı tanımıyorum, ama sefalet o kadar soğuk ki, çevresindeki kalpleri buz gibi yapıyor. (s.18)

9. On altıncı yaşında ziyaret edilen bu kız uyuyordu ve böyleye önümde bakire bir kız var, diyordum kendimce. (s. 26)

10. Kendimi yine işe verdim, ama isteksizlikten daha işin başında, birinci saatte yoruldum.
Gösterge 1= Ben (Başlı başına bir öznellik unsuru ve cümlenin ana öznesidir). Öznellik göstergesidir.

Gösterge 2= Dostlar-1-m (1. tekil şahıs iyelik eki). Öznellik göstergesidir.

Gösterge 3= Benim için/Bana göre (öznellik ifadesi). Öznellik göstergesidir.

Gösterge 4= Çatı kat-1-m (1. tekil şahıs iyelik eki). Öznellik göstergesidir.

Gösterge 1= (Benim) üzer-i-m-de (1. tekil şahıs iyelik eki). Öznellik göstergesidir. Gösterge 2= (Ben) hissediyor-u-m (1. tekil şahıs eki). Öznellik göstergesidir.

Gösterge 1= (Ben) tanımıyor-u-m (1. tekil şahıs eki). Öznellik göstergesidir.

Gösterge 1= (Benim) ön-ü-m-de (1. tekil şahıs iyelik eki). Öznellik göstergesidir. Gösterge 2= (Ben) diyor-du-m (1. tekil şahıs eki). Öznellik göstergesidir.

Gösterge 3= Kendi (Kendine dönüşlülük zamiri ile öznellik sağlanmıştır). Öznellik göstergesidir.

Gösterge 1= Kendimi (Kendine dönüşlülük zamiri ile öznellik sağlanmıştır). Öznellik göstergesidir.

Gösterge 2= (Ben) ver-dim (1. tekil şahıs eki). Öznellik göstergesidir.

Gösterge 3= (Ben) yorul-du-m (1. tekil şahıs eki). Öznellik göstergesidir.

Açıklama ve yorumlar: Yukarıdaki tabloda öznellik içeren etkisözlü sözceler incelendiğinde;

Birinci örnekte, "dinliyorum" ve "duyabiliyorum" yüklemlerinde bulunan /um/ 1. tekil şahıs ekinin kullanımı sonucu oluşmuş öznel bir durum ifadesi mevcuttur. Ayrıca "-e bilmek" yeterlilik kipinin kullanımıyla kişi kendi durumu hakkında kesinlik bildirmeyen yargılara ulaşır. Bu göstergelerden hareketle bu sözceyi öznellik bağlaminda bir etkisöz olarak değerlendirebiliriz.

İkinci örneğe baktığımızda, "çocuk muyum?" soru/sorgulama biçimi yazarın kişisel durumunu, içindekileri ortaya dökmesi sonucu karşı tarafa sorular soruyormuş ve ondan cevap bekliyormuş hissini vermektedir. Oysa işlev olarak kişinin kendisini sorgulamasina yarayan "öz soru" (Fr. auto-question) yani doğrudan kendisine yönelttiği soru biçiminde olan dilsel yapıdır. Başka bir ifadeyle, monolog görünümlü bir sözcedir. Bu yönüyle, konuşan öznenin kendisine yönelik duygusal ve ünlemsel değer taşıyan bir soru sözcesi olarak değerlendirilebilir. Yüklemdeki /-m/ 1. tekil şahıs ekinin kullanımı, yazarın kendi şahsi duygu ve düşüncelerinin öznel bir kanıtı şeklindedir. 
Konuşucunun kendisini işaret eden bu tür yüklemlere "öznellik yüklemi” adını verebiliriz.

Üçüncü örnekte, "tercih ederim" yüklem öbeği genel bir düşüncenin öznelleşmesidir. Yine 1. tekil şahıs eki olan /-m/ sayesinde, öznellik olgusu bir biçimbirimsel göstergenin kullanımıyla sağlanır. Bu da bir öznellik yüklemidir.

Dördüncü örnekte, "duyuyorum..." bir diğer öznellik yüklemidir; suskunluk/sesizlik diye tabir edilen olgunun içindeki sesin (bir nevi kalbin sesi ve tepkisi) duyulması bağlamında bir etkisözdür. Çünkü sessizlik içinde bir sesin duyulması, hele ki onun kalp sesi olması, konuşucunun ruh halini yansıtan bir duygu durumunun ifadesidir.

Altıncı örnekte bulunan "Ben, Benim için” ifadeleri bu sözcede doğrudan konuşan öznenin kendisi tarafından kişisel duygu, düşünce ve yaşantısından kesitler anlatmak için kullanılmıştır. "Ben" kişi zamiri, nesnellikten uzak bir anlatımı ele alırken; "benim için" iyelik zamirindeki "için" edatı ile öznellik pekiştirilmiş ve tabir yerindeyse sözce "ben"i anlatması ile öznellik bağlamında bir etkisöz olarak değerlendirebilir.

Yedinci örnekte, "üzerimde... hissediyorum" sözcüklerinde karşımıza çıkan etkisöz durumu, (benim) üzeri-m-de kelimesinde, 1. tekil şahıs iyelik eki ile yapılırken; (ben) hissediyor-u-m yükleminde ise 1. tekil şahıs eki ile yapılmış ve öznel bir ifadeyi yansıtmıştır. Dolayısıyla, bunlar da öznel yüklemler daha doğrusu öznellik yüklemleridir.

Sekizinci örnekte, "(Ben) dünyayı tanımıyorum” sözcesinde etkisöz durumu "tanımıyorum" yüklemiyle yapılmış, yine öznel bir yargıda bulunulduğu için aynı şekilde etkisöz bağlamında değerlendirilmiştir.

Dokuz ve onuncu örnekleri incelediğimizde, ortak kelime olan "kendi" göstergesi bir dönüşlülük zamiridir. "Kendimi ve kendimce" kelimeleri, cümleye kişinin kendinden etkilenmesi sonucu, öznellik bağlamında kendi düşüncelerini tekrar etmesi anlamını katar. Bu kendine dönüşlülük zamirini bir öznellik göstergesi olarak değerlendirebiliriz.

Yukarıda incelenen örnek sözcelerde, yazarın içinde bulunduğu psikolojik ve sosyal durum yine yazarın gözünden anlatılmış, geleceğe dair beklenti ve umutlardan bahsedilmiştir. Bunlar roman kahramanı üzerinden (Claude) anlatıldığından, yazarın kendisini (ve hayatını) Claude (ve hayatı) ile bir şekilde özdeşleştirdiğini söyleyebiliriz. Diğer bir ifadeyle, belirli ölçüde kurgu olsa da Claude'un hayatında yaşadığı olayların benzerini Zola zamanında yaşamıştır. Sözce, baştan itibaren öznel ifadelere yer vermekle beraber, konuşan öznenin geçmişte çektiği sıkıntılar sonucunda geleceğe dair sözleri, tutumları etkisöz bağlamında değerlendirilebilir.

\section{Dilbilgisel Gösterge İçeren Etkisözler}

Şimdi de ikinci kategoriye geçelim. Dilbilgisel gösterge olarak adlandırdığımız bu kategori daha çok dilbilgisi konularını içine alır. Dilbilgisi kurallarının yerinde ve uyumlu kullanımları, etkisöz bağlamında okuyucuyu etkileyeceği gibi, dilbilimsel bir ahenk unsuru olarak da görülebilir. Bu bağlamda, dilbilgisel göstergeleri kendi içinde 
üç bölümde inceleyebiliriz:

a) Kipsel özellikler içeren etkisözler (Kipsel etkisözler): Sözcelerdeki her türlü kipsel uyumu içine alan, bunun sonucunda sözce ve söylemde etki yaratan etkisözlerdir. Bunlara kısaca "kipsel etkisöz" (Fr. perlocution modale) de diyebiliriz.

b) Yüklem özellikleri içeren etkisözler (Yüklemsel etkisöz): Sözcelerdeki, özne-yüklem ve nesne-yüklem arasındaki uyum yahut emir ya da ünlem sözcelerinin yerinde kullanımı sonucu oluşan ve karşı tarafa etki eden sözcelerdeki etkisözlerdir. Bunlara kısaca "yüklemsel etkisöz" (Fr. perlocution prédicative) de diyebiliriz.

c) Niteleme işlevi olan etkisözler (Niteleyici etkisöz): Yazarın yahut söyleyenin yapmış olduğu etkileyici benzetmelerdir. Bir olayın, kişinin veya durumun çarpıcı bir şekilde tasvir edilmesi, karşı tarafta etki bırakması durumudur. Bunlara kısaca "niteleyici etkisöz" (Fr. perlocution épistémique) de diyebiliriz.

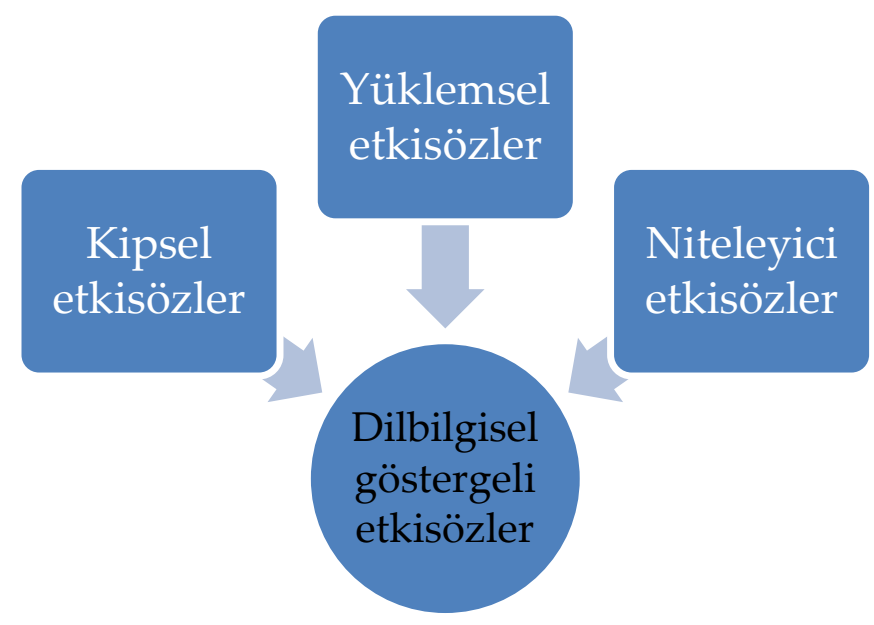

Şekil 4: Dilbilgisel göstergeli etkisöz kategorileri

Aşağıdaki tablo incelendiğinde, niteleme işlevi olan etkisözlerin "edat, bağlaç, sıfat, isim, yüklem" gibi sözcük düzeyinde olduğu gibi, sıfat-fiil, dilek-şart gibi kipler, görünüş ve zaman ekleri gibi biçimbirimler düzeyinde de gösterge barındırdığı görülebilir.

Tablo 2: Dilbilgisi Göstergesi İçeren Etkisözlü Sözceler

\begin{tabular}{l|l}
\hline \multicolumn{1}{c|}{ Dilbilgisel Gösterge İçeren Etkisözler } & \multicolumn{1}{c}{ Göstergeler } \\
\hline 1. İste beş hafta geçti. (s.15) & $\begin{array}{l}\text { Gösterge 1= Işte: Sözce başında kullanıld1- } \\
\text { ğında gösterme ya da belirtmeye kesinlik } \\
\text { katar. } \\
\text { Gösterge 2= Geç-ti: Fiilin görülen/bilinen } \\
\text { geçmiş zaman ile çekimlenmesi kesinliğin, } \\
\text { yaşanmışlı̆ı̆ göstergesidir. }\end{array}$ \\
\hline
\end{tabular}


2. Gerçeğin yüce sanatına sahip olsaydım, insani bir cennetin bilincine varsaydım, hayalle gerçeği ayırt edebilseydim, konuşurdum. (s.39)
3. Eğer, kendimi yalnız hissedersem, kendime bir eş yaratırım. (s.17)

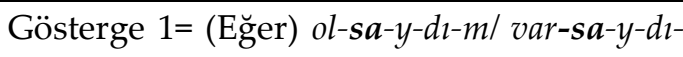
$m /$ et-e+bil-se-y-di-m: Dilek/şart kipi kullanimiyla öznel yarg1.

Gösterge 2=Konuş-u- $r-d u-m$ : Geniş zamanın hikâyesi ve 1. tekil şahıs kullanımıyla öznel ifade. Burada, şart kipi ve geniş zamanın hikâyesi arasındaki anlamsal ve kipsel uyumdan söz edebiliriz.

Gösterge 1= Ĕ̆ger: Sözce başındaki kullan1mıyla ihtimal yahut şart anlamı katar.

Gösterge 2=His-et-e-r-se-m:/-se/ şart kipiyle sözce pekiştirilmiş, kipsel bir uyum sağlanmıştır.

4. Çirkin bir kadındı: kapalı gözleri kirpikten yoksundu, şakakları düşük ve oynaktı, ă̆zı büyük ve cansizdı (...) (s.24)

Gösterge 1= Çirkin bir kadın: Niteleme sıfatı. Gösterge 2= Düşük ve oynak şakaklar: Niteleme sifatı.

Gösterge 3= Büyük ve cansız ă̆ız: Niteleme sifatı.

5. Titreyen dudaklar öpücüklerini ararlar; kırlarda yer bulamayan âşıklar, sığınakların önünde acele ederek yağmurun, sonsuz baharın gürültüsü altında, çatı katlarına sı̆̆ınırlar. (s.13)

Gösterge 1= Titreyen dudaklar: /-en/ partisip ekiyle niteleme sıfatı kullanımıyla öznel bir benzetme yapılmıştır.

Gösterge 2= Kırlarda yer bulamayan âşıklar: /-an/ partisip ekiyle niteleme sıfatı ve öznel yarg1.

6. İşte kış günü (...) (s.13)

7. Can sıkıcı, duvar kâğıtlarının koyulaştırdığ̆ı, çirkin camekânli, solgun çiçekli çini vazoların bulunduğu evin önünde duraklıyorum. (s.13)

Gösterge 1= İşte: Gösterilmek ya da kanıtlanmak istenen durum göstergesi.

Gösterge 2= Günü(dür): Gizli /-dir/ bildirme ekiyle kipsel bir uyum sağlanmış, isim yüklemi oluşmuştur.

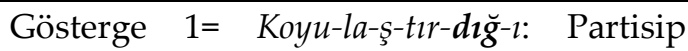
ekiyle isme öznel nitelik katma.

Gösterge 2= Çirkin camekânll, solgun çiçekli çini vazolar: Niteleme sıfatlarıyla öznel yarg1).

8. Sokak, bizim tek mekânımız; bunun dışındaki yerler evimiz değildir. (s.35)

Gösterge 1= Tek mekânımız(dır): Mekâna odaklama ve mekânı belirtme durumu, gizli /-dır/ ekiyle isim yüklemi yapılmıştır. Gösterge 2= Evimiz değil-dir: Yine aynı durum karşımıza çıkar; /-dır/ ek fiillinin kullanımı sonucu yüklemsel bir uyum yakalanmış ve etki sağlanmıştır.

9. İşte, mücadelenin tam ortasındasın. (s.15)

10. Tasarladiklarını hatırla: hareketlerinde $k a$ rarlı ve dürüst ol, tıpkı düşlerinde olduğu gibi; çatı katlarında yaşa, katı ekmeğini ye, yoksulluğa gülümse. (s.15)
Gösterge 1= İşte: Sözce başı edatıyla duruma odaklanılmış; okuyucuda farkındalık yaratacak bir etki yaratılmaya çalışılmıştır).

Gösterge 1= Hatır-la / kararlı ve dürüst ol / yaşa / ye / gülümse: 2. tekil şahıs emir/buyurma kipiyle yazar tarafından okuyucuya nasihat verilmiştir. Bu sebeple sözce etkisöz bağlamında değerlendirilebi- 
lir.

11. Esmer, gülmeyi seven kızlar, ürünlerin ve intikamların kraliçeleri, başak ve salkımlarla süslenmiş, cıvıl cıvıl gençliklerine kendilerini kaptırırcasına, eğleniyorlar, patikalarda koşuşuyorlard1. (s.15)
Gösterge 1= Esmer, gülmeyi seven kızlar: Niteleme sifatı ve sifat tamlamasıyla öznel etkisöz yapısıdır.

Gösterge 2= Gülmeyi sev-en kızlar: Partisip ekiyle etkisöz kullanımı vardır.

Gösterge 3= Süs-le-n-miş: Partisip ekiyle etkisöz kullanımı söz konusudur.

Gösterge 4= Civıl cıvıl gençlik: Niteleme sıfatıyla etkisöz kullanımı içermektedir.

Açıklama ve Yorumlar: Dilbilgisel gösterge içeren etkisözler incelendiğine;

Birinci örnekte, "işte" ve "geçti" kelimelerinden oluşan etkisöz öğeleri, bir durumu kanıtlama, tabir yerindeyse gösterme ve inandırıcılık anlamı katar.

İkinci örnekte, "olsaydım, varsaydım, edebilseydim, konuşurdum” yüklemlerinde aradığımız etkisöz öğeleri, "ihtimal, olasılık" anlamı taşımakla birlikte, bir hikâye anlamı da taşır (şart kipinin hikâyesi). Kısaca, "eğer bu durum böyle olsaydı, ben de böyle davranırdım" anlamı ya da alt yorumu taşıyan sözcede, geniş zamanın şartı ile uygun kipsel uyum yakalanmış ve etkisöz bağlamında değerlendirilmiştir.

Bir önceki örnekte olduğu gibi, üçüncü örnekte de "eğer" bağlacı ve "hissedersem" yükleminde etkisöz unsurları aranır. Çünkü "eğer" bağlacı ve şart kipi eki diye tabir edilen /-sa/, /-se/ sözceye ihtimal ve koşul anlamı kattığı gibi, kipsel bir uyumun da içerisindedir.

Dördündü örneğe baktığımızda, "çirkin bir kadındı, kapalı gözleri kirpikten yoksundu, şakakları düşük ve oynaktı, ağzı büyük ve cansızdı" sözcesinde, niteleme sıfatları vasıtasıyla yoğun betimleme yapılmış ve bu durum, karşıdaki kişiyi canlı bir şekilde resmetmiştir. Niteleme gücünden dolayı etkisöz bağlamında değerlendirilebilir.

Beşinci örnekte, "titreyen dudaklar" ve "yer bulamayan âşıklar" ifadelerindeki /-an/ partisip eki ile yapılmış sıfat tamlamalarını içeren örnekler sözceye betimleyici bir anlam katmış ve etkisöz bağlamında değerlendirilmiştir.

Altıncı örnekteki "İşte kış günü" ifadesinde, bir kış günü veya kış tablosu "işte" edatıyla okuyucuyu kışa odaklandırmış ve kanıtlama anlamı taşımıştır. Bu sebeple kipsel uyum bağlamında bir etkisöz olarak değerlendirilebilir.

Yedinci örnekte, "koyulaştırdığı̆, çirkin camekânlı, solgun çiçekli çini vazolar..." ifadelerindeki etkisözler, /-dık/,/-dik/ partisip eki ile yapılmış sıfat tamlaması ve niteleme sıfatlarıyla oluşturulmuştur.

Sekizinci örnekte, "tek mekânımız(dır)" ve "değildir" kelimelerinde /-dır/ bildirme eki ile yüklemsel bir uyum yakalanmış ve etkisöz bağlamında değerlendirilmiştir. 
Dokuzuncu örnekte, "İşte" edatıyla başlayan sözcede bir odaklama ve kanitlama durumuna gidilmiş, bu durum etkisöz bağlamında değerlendirilmiştir.

Onuncu örnekte, "hatırla, kararlı ve dürüst ol, ye, gülümse, yaşa" yüklemlerinde emir kipi kullanılmıştır. Buradaki etkisöz bağlamı, hayata dair nasihatlerin emir kipiyle yapılması durumudur. Çünkü normal şartlarda nasihatler emir kipiyle verilmez. Emir kipiyle işlenmesi yorumsal açıdan bakınca bunu kendin için yapmak zorundasın anlamını verir. Bu sebeple etkisöz bağlamında yüklemsel bir uyum içerisinde gösterilebilmektedir.

Son örneği incelediğimizde, "Esmer, gülümsemeyi seven kızlar" ve "süslenmiş, cıvıl cıvıl gençlik" ifadelerindeki etkisözler dikkate değerdir. /-me/, /-en/, /-miş/ sıfatfiil (partisip) ekleriyle oluşturulmuş sıfat tamlamaları ve niteleme sıfatları, cümleye betimleme anlamı katmakla birlikte bir etkisöz durumu da oluşturmuştur. Dildışı unsurlar içeren etkisözlerin (22-34 arasındaki örnek sözceler) dilsel göstergeleriyle ilgili açıklamalar yeterli görüldüğü için burada açıklama yapılmamıştır.

\section{Dildışı Gösterge İçeren Etkisözler}

Dilsel olmayan / Dildışı gösterge (İng. non-linguistig mark / extralinguistic sign) adıyla da bilinen bu kategori, dil ve söylem dışında kalan, kaş-göz hareketleri, bakış gibi beden dilini kapsayan çeşitli yüz ifadelerini yansıtan jest ve mimikler, sesli ünlemler ve seslenmeler gibi unsurların kullanıldığı sözsüz iletişim kanalıdır. Yazı yahut sözlü iletişimdeki her dildışı öğe, etkisöz bağlamında değerlendirilemeyeceği gibi, karşı tarafa etkisi, odaklama amaçlı olarak yerinde kullanımı sonucu etkisöz olarak kabul edilebilir. Aşağıdaki tabloda gösterilen sözceler, dildışı kategoriler temel alınarak etkisöz bağlamında değerlendirilecek ve yorumlanacaktır.

Tablo 3: Dildışı Etki Yaratan Etkisözlü Sözceler

\begin{tabular}{|c|c|}
\hline Dildışı Etki Yaratan Etkisözler & Göstergeler \\
\hline $\begin{array}{l}\text { 1. Ah! Seslerimizin çatı penceresi ne kadar da be- } \\
\text { yazd1! (s.15) }\end{array}$ & $\begin{array}{l}\text { Gösterge } 1=A h !: \text { Seslenme ünlemi olarak bir } \\
\text { iletişim şeklini yansıtır (duygu durumu, öznel- } \\
\text { lik). } \\
\text { Gösterge 2= Beyazdı!: Ünlem işareti konuşan } \\
\text { öznenin kişisel düşüncesini, öznelliğini yansıtır. }\end{array}$ \\
\hline 2. Oh! Hayat ne kadar genç ve tutkulu olurdu! (s.19) & $\begin{array}{l}\text { Gösterge } 1=\text { Oh!: Seslenme ünlemi olarak bir } \\
\text { iletişim şeklini yansıtır (duygu durumu, öznel- } \\
\text { lik). } \\
\text { Gösterge } 2=\text { Olurdu!: Ünlem işareti konuşan } \\
\text { öznenin kişisel düşüncesini, öznelliğini yansıtır. }\end{array}$ \\
\hline $\begin{array}{l}\text { 3. Bağışlayın kardeşlerim, ipek o kadar yumuşak, } \\
\text { dantel o denli hafif ki, güneş altın ve kristalin içinde } \\
\text { öylesine neşeyle gülüyor ki! (s.17) }\end{array}$ & $\begin{array}{l}\text { Gösterge } 1=\text { Neşeyle gülmek: Duygu durumunu } \\
\text { (mutluluk) yansitan bir yüz ifadesidir. }\end{array}$ \\
\hline $\begin{array}{l}\text { 4. Ah! Yeteneğin temelinin yoksulluk olduğunu } \\
\text { iddia edenler, nasıl da yalan söylüyorlar. (s.32) }\end{array}$ & $\begin{array}{l}\text { Gösterge } 1=A h !: \text { Seslenme ünlemi olarak bir } \\
\text { iletişim şeklidir (duygu durumu, öznellik). }\end{array}$ \\
\hline
\end{tabular}




\author{
5. Laurence ayăga kalktt. Yüzünü acllı ve alaycı bir \\ ifade almıştı. (s.36)
}

6. Zavallı kız, erkek kardeşlerinin bağırmalarından ürktü. Gülümsedi ve onları daha uzun bir süre görmek için yüzünü çevirdi. (s.40)
Gösterge 1= Ayağa kalkmak: Bir vücut hareketini betimler.

Gösterge 2=Acll ve alaycl bir ifade: Duygu durumunu yansitan yüz ifadesini betimler.

Gösterge 1= Ürktü: Duyguların dışa vurumu, bir çeşit vücut jestidir.

Gösterge 2= Gülümsedi: Sözün olmadığı bir iletişim şekli, bir mimiktir (dildışı iletişim).

Gösterge 3= Yüzünü çevirdi: Bir vücut jestidir.

7. Artık, üşümüyor, ama titriyordum. Damarlarım, belirsiz bir ateşle atıyordu. (s.26)

Gösterge $1=$ Üşümüyor ama titriyordum: $\mathrm{Bu}$ ifadede "üşümek" fizyolojik bir durum iken, titremeye geçmek şiddetli bir duygu durumunun betimlemesidir.

8. Kız iç çekerek, yorganın üzerinden diğer yana döndü. Göğsünü açığa çıkaracak şekilde örtüyü üzerinden çekti. (s.26)

Gösterge 1= İ̧̧ çekerek: Kızın duygu durumunu anlatan bir ifadedir. İç çekmesi, üzgün ve ağlamaklı olduğunu gösterir.

Gösterge 2= Diğer yana döndü... örtüyü üzerinden çekti: Yüklemlerinde tasvir edilen vücut hareketi sözsüz iletişim kapsamında değerlendirilir.

9. Kız uyandı ve beni yanı başında bulmaktan şaşırmış görünmeyerek, bana gülümsedi. Bu gülümseme belirsizdi, sanki bir kalabalığa hitap ediyordu. (s.27)

Gösterge 1= Şaşırmış görünmeyerek: Kişinin duygu durumunu açığa çıkaran mimiktir.

Gösterge 2= Gülümsedi: Gülümsemek, sözsüz bir iletişim ve mimiktir.

Gösterge 3= Gülümseme belirsizdi: $\mathrm{Bu}$ ifade kişinin duygu durumundan bizi haberdar eder ve mimik hareketidir.

10. Hafif bir uyku, dudaklarına belirsiz bir gülümseme vermişti; yüz çizgileri gevşemişti, acısının geçmesi, çirkinliğe yumuşak ama acı bir çeşit güzellik katmıştı. Üzüntülü ve boyun eğmiş haliyle uyuyordu. (s.25)

Gösterge 1= Yüz çizgileri gevşemişti: Bedensel ve ruhsal rahatlamanın dıșa vurumu, sözsüz bir iletişimdir.

Gösterge 2= Üzüntülü ve boyun eğmis haliyle: Üzüntülü ve boyun eğmiş olmak birer duygu durumudur. Bu duyguların yüze yansıması,

11. Ağız boşluğunu gösterecek şekilde gülüyordu. Çekingen aşklara karşı ihtiyarlığın bu gönül hoşluğu beni utandirdl. (s.30)

Gösterge 1= Gülüyordu: Burada yine duygu durumunu anlatan mimiksel bir hareket vardır.

Gösterge 2= Utandırdl: Utanmak bir duygu iken, kişinin utanması duygu durumunun açığa çıkışıdır. Vücut jesti olarak da değerlendirebiliriz.

12. Ah! On beş yaşında olsaydım! (s.31)

Gösterge 1=Ah!: Bir ünlem olmasıyla birlikte, dilsel olarak da bir anlam ifade etmez ve bir anlaşma ifadesi değildir. Sadece, jest ve mimikler gibi, kişinin duygu durumu hakkında bilgi verir. Bu sebeple, dildışı bir öğedir.

13. Çok öfkelenmiştim. Hareketlerimle onu tehdit ettim, yanından geçerken de bulabildiğim en küçük düşürücü şeyi yaptım. (s.46)

Gösterge 1= Öfkelenmiştim: Öfkelenmek de bir duygu durumudur. Kişinin yoğun duygularının hareket ya da mimik olarak dışarı çıkışıdır.

Gösterge 2= Hareketlerimle onu tehdit ettim: Burada çok bariz bir şekilde sözsüz iletişim örneği vardır. Hareketlerle tehdit etmek, bedensel ya da mimiksel bir iletişim, kısacası beden dilidir. 
Açıklama ve Yorumlar: Dilbilgisel gösterge içeren etkisözler incelendiğine;

Ah!: Bir ünlem olmasıyla birlikte, dilsel olarak da bir anlam ifade etmez ve bir anlaşma ifadesi değildir. Sadece, jest ve mimikler gibi, kişinin duygu durumu hakkında bilgi verir. Bu sebeple, dildışı bir öğedir.

Oh!: Bir ünlem olmasiyla birlikte, dilsel olarak da bir anlam ifade etmez ve bir anlaşma ifadesi değildir. Sadece, jest ve mimikler gibi, kişinin duygu durumu hakkında bilgi verir. Bu sebeple, dildışı bir öğedir.

Neşeyle gülmek: Anlaşma ibaresinden ziyade bir çeşit bağlamsal duygu durumu ve yüze yansıyan bir tebessüm, bir mimiktir.

Ah!: Bir ünlem olmasıla birlikte, dilsel olarak bir anlam ifade etmez ve bir anlaşma ifadesi değildir. Sadece, jest ve mimikler gibi, kişinin duygu durumu hakkında bilgi verir. Bu sebeple, dildışı bir öğe olarak değerlendirilebilir.

Ayağa kalkmak: Bir vücut jestidir ve ayağa hangi duygularla kalkıldığı önemlidir. Ayağa kalkmak, somut bir sözlü iletişim unsuru değildir.

Yüzdeki acılı ve alaycı bir ifade: Kişinin duygu dünyası hakkında bilgi sahibi olmamızı sağlayan mimiklerdir.

Ürktü: Duyguların dışa vurumu, bir çeşit vücut jestidir.

Gülümsedi: Bir yüz ifadesi, duygu durumunu yansıtan bir mimiktir.

Yüzünü çevirdi: Bağlamsal duygu durumunu dışa vuran bir vücut jestidir.

Roman, diyalog ya da monolog şeklinde konuşma dili ağırlıklı olduğu için yukarıda incelenen etkisözlü sözceler ve dildışı göstergeleri oldukça yoğun olarak kullanıldığını söyleyebiliriz. Özellikle karşılıklı konuşma durumlarında, dıldışı unsurların bulunduğu sözcelerde, konuşucunun muhatabına karşı ya da okurun gözünde belirli bir etkisöz yarattığını söylemek mümkündür.

\section{Sonuç}

Emile Zola'nın "etkisöz" bağlamında incelenen eserinde öncelikli olarak biçim, biçem ve anlam ilişkisi açısından oldukça yoğun sayılabilecek betimlemeler ve buna bağlı olarak da naturalist yani doğal unsurlar göze çarpmaktadır. Edebiyatta doğalcılık ak1mı (naturalizm), hayata, doğaya ve insana ilişkin her şeyi sansürsüz bir şekilde tüm gerçekliği ve çıplaklığı ile ele alan, gösteren, Fransa'da ortaya çıkmış bir edebî akımdır ve Emile Zola da bu akımın en önemli temsilcisi, öncüsüdür. Tüm dünyada ölümsüz klasik yazar olması ve yapıtlarının geçerliliğini koruyarak halen okunuyor olmasının altında toplumlarda sosyo-kültürel ve felsefî boyutta derin izler birakmasından kaynaklanır. Dolayısıyla, Zola gibi yazarlar sadece düz bir yazar olarak görülmemeli; evrensel değerleri yazarlığın yanı sıra, düşünür, felsefeci, edebiyatçı gibi çok yönlü kişiler olarak kabul edilir.

Etkisözün oluşumuna da etki eden bu natüralist unsurların gerçek bağlamsal anlamları, metnin özellikle örtük yapısında (Fr. implicite), yananlam olgularında (Fr. connotation), dolayısıyla da derin yapısında (Fr. structure profonde) kendini gösterir. $\mathrm{Bu}$ gibi çok boyutlu ve derin dilsel olgu ve olayları inceleme ve yorumlamanın zorluğu 
da buradan kaynaklanır. Gerçekliğin etkili bir şekilde alenen gösterilmesi, karşı tarafı hem duygusal hem de fiziksel olarak doğrudan etkileyen bir olgudur; çünkü hayata dair gerçekler ve göstergeleri, her zaman en etkili unsurlardan biridir. Bu sebeple, etkisöz olgusu "odaklama" olgusuna (Fr. focalisation) çok yakın ve ilişkili olduğundan birlikte değerlendirilebilir, zira her iki dilsel olguda da işlevsel açıdan bağlamın belirli bir noktasını işaret eder, vurgu yapar ve bunu yaparken de karşı tarafa yönelik (alıcı olarak okur) etki faktörü çok önemlidir, yani niyet olarak muhatabı etkilemek, kafasında iz bırakmak ön plandadır. Diğer yandan, bu gibi klasik yapıtlar tek yönlü ve kısıtlı olarak sadece edebiyatla açıklanamaz; özellikle dilsel ve söylemsel çalışmalarda başta dilbilim olmak üzere, göstergebilim, sosyoloji, felsefe gibi farklı sosyal bilim alanlarını da kuşkusuz disiplinlerarası bir yaklaşımla bu incelemelere dâhil etmekte yarar vardır. Çokdisiplinli boyutta edimbilimsel (pragmatik) yaklaşımla derinlemesine yapılan kapsam1 araştırmalar ister istemez bu yaklaşımı gerektirir.

Bir dilsel olgu ve oluşum olarak “etkisöz”, yazı dili yahut sözlü dil üzerinden kendini gösterebilir, fakat özellikle klasik eserlerdeki etkisöz unsurları, etkisözün evrensellik, nesnellik özelliğini ortaya çıkarır. İki kişi arasındaki bir konuda etkisöz öznel olarak ele alınır, çünkü sözcenin alıcısı bir kişi olduğundan bireysel özelliktedir. Fakat insanlığın ortak sorunları doğrultusunda ele alınan etkisözler, daha geniş bir kesime ulaşır ve toplumsal özellik taşır. Bu bağlamda, klasik eserler etkisöz yahut sözcelerin yoğun kullanıldığı metinlerdir. Klasik yazarlar bireysel özellikteki etkisözlerden yola çıarak toplumları ve genel toplumsal olguları kapsayacak şekilde (deyim yerindeyse tüm insanlığa hitaben) ve yapitlarının sonucunda ders verecek nitelikte sosyo-kültürel iletiler aktarmayı amaçlar.

Romanda iletişimsel boyut üzerinden ele alınan gönderen, mesaj, alıcı unsurlar1na yönelik göstergeler, derin - yüzey yapı çerçevesinde farklı kiplikler, yan - düz anlam, dildışı öğeler ve öznellik - nesnellik konuları üzerinden incelenmiş ve etkisözün oluşumuna katkıları örneklerle gösterilmeye çalışılmıştır. Kuşkusuz Zola'yı Zola yapan (bu çalışmada ortaya koymaya çabaladığımız) kendine özgü edebî dil ve söylem kullanmasının yanı sıra, metnini kaleme alırken biçim ile biçemi (Fr. forme et style) birbiriyle olabildiğince uyumlu ve etkili bir şekilde sentezleyerek ortaya koymasındandır. Dolay1sıyla, dil ve edebiyatı iyi harmanlaması eserini üslup bakımından etkili kılan ve deyim yerindeyse ölümsüzleştiren bir özelliktir. Sonuç olarak, Zola'nın bu yapıtında etkisöz barındıran sözceleri bu manada kendine özgü etkileyici hatta odaklayıcı bir söylem biçimi olarak değerlendirilebilir. Bu açıdan bakıldığında, özellikle Zola gibi edebiyatta çığır açan klasik yazarların toplumlara mal olmuş edebî eserlerini bu bağlamda farklı gözlerle okumak (okuyabilme yetisi), okurlara sadece edebiyatta değil diğer sosyal alanlarda da kuşkusuz akademik olarak daha farklı edim ve kazanım sağlayacaktır.

\section{KAYNAKÇA}

El Arabi, Abdülmecid (1983). Taalumu'l-Luğati'l-Hayye ve Ta'limuha beyne'nNazariyyeti ve't-tatbik (Teoride ve pratikte yaşayan dillerin öğrenimi ve öğretimi). (Çev.: G. Sebati Işkın). Cumhuriyet Üniversitesi İlahiyat Fakültesi Dergisi, 3, 535-549. https://dergipark.org.tr/tr/download/article-file/223696 
Aksan, D. (1990). Her yönüyle dil. TDK - Türk Dil Kurumu.

Kocaman Gürata, E. (2018). Yabancı dil olarak Türkçe öğretiminde sözceleme kuramından ve edimbilimden hareketle örnek ders malzemesi geliştirilmesi. IJLA International Journal of Language Academy, 6 (26), 278-291. http://dx.doi.org/10.18033/ijla.4031

Saussure, F. (1998). Genel dilbilim dersleri (Çev.: B. Vardar). Multilingual Yabancı Dil Yayınları.

Bloomfield, L. (1942). Outline guide for the practical study of languages. Baltimore, Linguistic Society of America.

Chomsky, N. (2011) Dil ve zihin (3.baskı), (Çev.: A. Kocaman). Bilgesu Yayınları.

Vardar, B. (2007). Açıklamalı dilbilim terimleri sözlüğü. Multilingual Yabancı Dil Yayınlar1.

Yılmaz, S. ve Çalışır, C. (2018). Klasik bir edebi romanda öznellik barındıran sözcelerin toplumdilbilimsel yorumu. Journal of International Social Research, 11 (59), 268 277. http://dx.doi.org/10.17719/jisr.2018.2635

Zola, E. (2011). Claude'un itirafları (Çev.: S. Yılmaz). İdeal Kültür Yayıncılık.

\section{Katkı Belirtme / Teşekkür:}

Bu çalışma Marmara Üniversitesi'nin eski adıyla BAPKO şimdiki adıyla BAP Birimi tarafında desteklenen B Tipi Çok Disiplinli Araştırma Projesi kapsamına girmektedir. Bahse konu bilimsel projemizin konusu "Batı Dilbilim Kuram ve Yöntemleri Işığında Türkçenin Konuşma Dili Yapısı ve İşleyişi (Pragmatik Yaklaşımlar)"dir. Projenin kodu: SOS-B-071015-0490. Kurumumuza ve ilgili birime buradan en içten teşekkürlerimizi sunuyoruz. 